\title{
Rotura espontánea de catéter doble $\mathrm{J}$
}

\author{
Barrero Candau R, Fernández Hurtado M, García Merino F. \\ Unidad de Urología Pediátrica. Hospital Universitario Virgen del Rocío. Sevilla.
}

\author{
Actas Urol Esp. 2008;32(7):770
}

$\mathrm{V}$ Tarón de 8 años de edad que en el primer control radiológico (a la semana) de ureteropieloplastia desmembrada de Andersson-Hynes mostró un catéter doble $\mathrm{j}$ integro y correctamente colocado. En la placa de control previa a su retirada (40 días después de su colocación) se comprobó la rotura espontánea del catéter en 2 fragmentos (Fig. 1). Por lo que se programó para ureteroscopia y extracción. En otra placa previa a la ureteroscopia se comprobó nueva rotura espontánea en tres fragmentos (Fig. 2). Los dos fragmentos inferiores se extrajeron por cistoscopia y ureteroscopia, mientras que el fragmento más craneal hubo que extraerlo mediante nefroscopia en el mismo

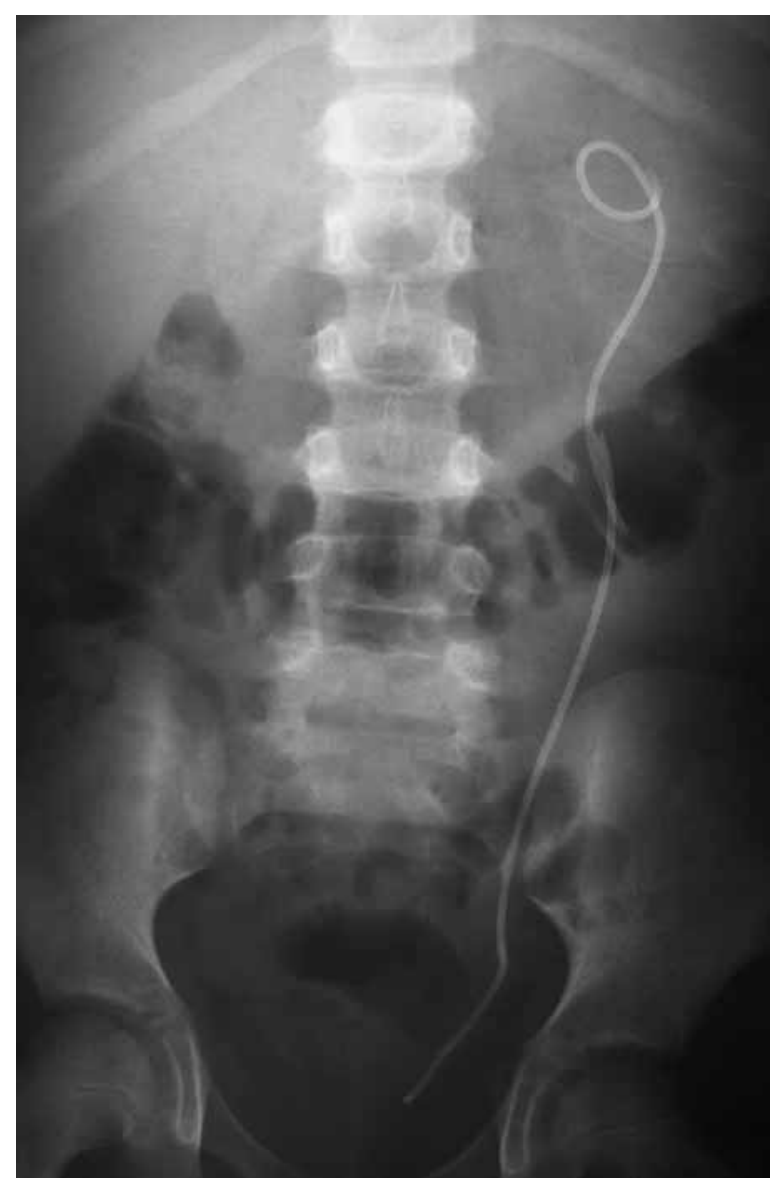

FIGURA 1 acto quirúrgico. Durante la intervención se comprobó que el catéter se fragmentaba con suma facilidad al traccionar de éste. Tras revisar la hoja de material implantable que se realiza en nuestro centro, se comprobó que el catéter no estaba caducado y se comunicó a la casa comercial el lote al que pertenecía.

Correspondencia autor: Dr. R. Barrero Candau Unidad de Urología Pediátrica.

Hospital Universitario Virgen del Rocío

Avda. Manuel Sirot, s/n - 41013 Sevilla

E-mail autor: rafaelbarrero@latinmail.com

Información artículo: Imágenes en Urología

Trabajo recibido: enero 2007

Trabajo aceptado: febrero 2007

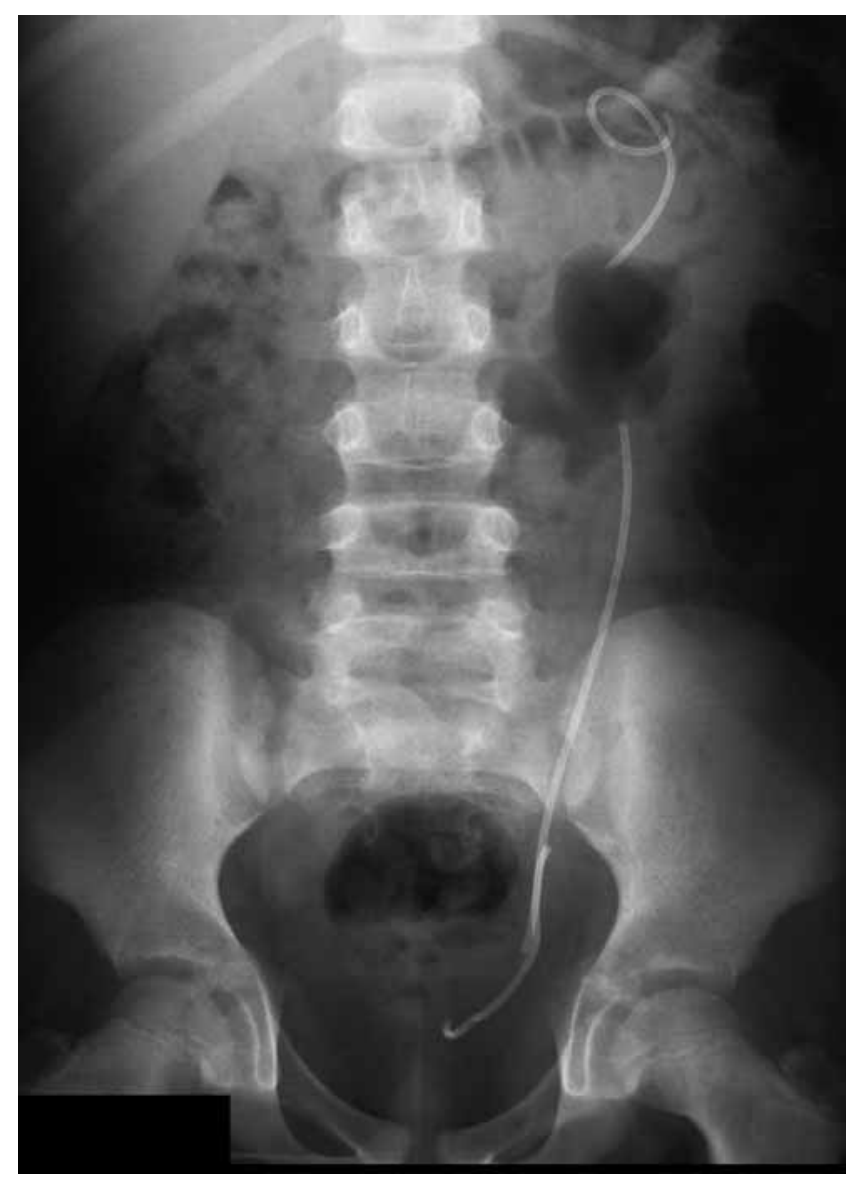

FIGURA 2 